\title{
The dynamics of energy metabolism in the tick embryo
}

\author{
A dinâmica do metabolismo energético em embrióes de carrapato \\ Renato Martins ${ }^{1}$; Newton Ruiz ${ }^{1}$; Rodrigo Nunes da Fonseca ${ }^{2,3}$; Itabajara da Silva Vaz Junior ${ }^{3,4}$; Carlos Logullo ${ }^{2,3 *}$ \\ ${ }^{1}$ Unidade de Experimentação Animal, Universidade Estadual do Norte Fluminense - UENF, Campos dos Goytacazes, RJ, Brasil \\ ${ }^{2}$ Laboratório Integrado de Bioquímica Hatisaburo Masuda, Núcleo em Ecologia e Desenvolvimento Sócio-Ambiental de Macaé, \\ Universidade Federal do Rio de Janeiro - UFRJ, Campus Macaé, RJ, Brasil \\ ${ }^{3}$ Instituto Nacional de Ciência e Tecnologia em Entomologia Molecular - INCT-EM, Rio de Janeiro, RJ, Brasil \\ ${ }^{4}$ Centro de Biotecnologia e Faculdade de Veterinária, Universidade Federal do Rio Grande do Sul - UFRGS, Porto Alegre, RS, Brasil
}

Received February 01, 2018

Accepted June 12, 2018

\begin{abstract}
The cattle tick Rhipicephalus (Boophilus) microplus is an ectoparasite capable of transmitting a large number of pathogens, causing considerable losses in the cattle industry, with substantial damage to livestock. Over the years, important stages of its life cycle, such as the embryo, have been largely ignored by researchers. Tick embryogenesis has been typically described as an energy-consuming process, sustaining cell proliferation, differentiation, and growth. During the embryonic stage of arthropods, there is mobilization of metabolites of maternal origin for the development of organs and tissues of the embryo. Glycogen resynthesis in late embryogenesis is considered as an effective indicator of embryonic integrity. In the cattle tick $R$. (B. (B.) microplus, glycogen resynthesis is sustained by protein degradation through the gluconeogenesis pathway at the end of the embryonic period. Despite recent advancements in research on tick energy metabolism at the molecular level, the dynamics of nutrient utilization during $R$. (B.) microplus embryogenesis is still poorly understood. The present review aims to describe the regulatory mechanisms of carbohydrate metabolism during maternal-zygotic transition and identify possible new targets for the development of novel drugs and other control measures against $R$. (B.) microplus infestations.
\end{abstract}

Keywords: Energy metabolism, embryogenesis, Rhipicephalus (B.) microplus.

\section{Resumo}

O carrapato bovino Rhipicephalus (B.) microplus é um ectoparasita capaz de transmitir diversos patógenos, sendo responsável por grandes perdas na pecuária pelos danos causados ao gado. Atualmente, muitos estudos têm negligenciado fases importantes do ciclo de vida deste parasita, como a fase embrionária. A embriogênese é classicamente descrita como um processo que demanda um consumo de energia, possibilitando a proliferação celular, diferenciação e crescimento. Além disso, em artrópodes, o estágio da embriogênese é caracterizado pela mobilização de metabolitos de origem materna para o desenvolvimento de novos tecidos e órgãos. A ressíntese de glicogênio no final da embriogênese tem sido descrita em diversas espécies de artrópodes, sendo considerada um indicador de integridade do embriáo. No caso do $R$. (B.) microplus a ressíntese de glicogênio é sustentada pela degradação de proteínas durante a gliconeogênese, no terço final da embriogênese. Apesar dos recentes avanços, no estudo molecular e do metabolismo energético, os mecanismos envolvidos na dinâmica da utilização de diferentes substratos energéticos durante a embriogênese do carrapato $R$. (B.) microplus ainda é pouco entendido. Diante deste panorama, estudos que descrevam a regulação destes mecanismos e da associação do metabolismo de carboidratos com a transiçáo materno zigótica, pode auxiliar na busca de novos alvos para o desenvolvimento de novos acaricidas e outras intervençóes para o controle infestaçóes de $R$. (B.) microplus.

Palavras-chave: Metabolismo energético, embriogenese e Rhipicephalus (B.) microplus.

\footnotetext{
*Corresponding author: Carlos Logullo. Laboratório Integrado de Bioquímica Hatisaburo Masuda, Núcleo em Ecologia e Desenvolvimento Sócio-Ambiental de Macaé, Universidade Federal do Rio de Janeiro - UFRJ, Av. São José Barreto, 764, São José do Barreto, CEP 27965-045, Macaé, RJ, Brasil. e-mail: carloslogullo@yahoo.com.br
} 


\section{Introduction}

Oviparous animals face embryogenesis in the absence of exogenous nutrient supply. In this case, maternal nutrients are packaged into the female oocytes during oogenesis (FAGOTTO, 1990; SAPPINGTON \& RAIKHEL, 1998). In arthropods oogenesis the oocytes exhibit fast growth, accumulate carbohydrates, lipids and proteins that will meet the regulatory and metabolic needs of the developing embryo (CHIPPENDALE, 1978).

The current literature provides ample information regarding metabolic events during larval and adult phases of several arthropods (BRIEGEL et al., 2003; GOLDSTROHM et al., 2003; ZHOU et al., 2004a,b; BROWN et al., 2008). Nevertheless, aspects concerning energy metabolism such as the activity of central metabolic pathways in arthropod embryogenesis or the determination of energy reserves to be used are scarce. In the fruit fly Drosophila melanogaster an increase in glycogen content strongly correlated with protein levels in follicles and young embryos has been described (SHIOMI \& KITAZUME, 1956; MEDINA \& VALLEJO, 1989; GUTZEIT et al., 1993). Histochemical studies reveal that glycogen is the predominant form of carbohydrate storage in D. melanogaster eggs (YAMAZAKI \& YANAGAWA, 2003). Furthermore, changes in protein content occur in an opposite direction to that determined for the carbohydrate content (GUTZEIT et al., 1993).

Thus, the regulation of glucose metabolism pathways and the dynamics of nutrient utilization in embryogenesis often differ from species to species. Therefore, studying these events in different arthropods allow us to understand the regulatory mechanisms of energy metabolism, finding potential targets for the development of vaccines and drugs against these diseases vectors.

\section{Embryogenesis in arthropod model}

The fruit fly $D$. melanogaster has been used as a model organism for the understanding of the molecular mechanisms that orchestrate arthropod development (OBER et al., 2012). There are many molecular and genetic tools available for studying the events involved in cell differentiation of $D$. melanogaster embryos and gene regulatory networks that control this process which makes this Diptera the best known multicellular organism (ROY et al., 2010). The understanding of the complex embryo gene regulatory networks and gene interactions may unravel the hidden secrets of insect evolution (DAVIS \& PATEL, 2002; LYNCH \& DESPLAN, 2003).

The pre-gastrulation embryo should be defined as a two-dimensional Cartesian coordinate system (NÜSSLEIN-VOLHARD \& WIESCHAUS, 1980) with bilateral symmetry and clear anterior-posterior (AP) and dorsal-ventral (DV) axes which are independent but develop simultaneously. Predetermined embryonic cell fate is possible if maternal mRNA is deposited in oocytes providing positional information that can be interpreted and refined by downstream target genes (NÜSSLEIN-VOLHARD et al., 1987). Combined approaches have been used to understand the transitions that occur in embryonic patterning strategies during the evolution of insects (PRPIC et al., 2008). One particular approach has generated greater understanding of insect embryogenesis. Comparing hemimetabolous and holometabolous insects with a short-germ type of development with those insects with a long-germ type of development such as Drosophila may reveal how gene regulatory networks evolved in insects and may also unravel common strategies that would be linked to the transition from short-germ type to long-germ type of embryogenesis (DAVIS \& PATEL, 2002).

During the early stages of its development, the embryo undergoes maternal-to-zygotic transition (MZT), which is a stage in embryonic development characterized by extensive mRNA degradation followed by the activation of zygotic transcription. During oocyte formation, the female lays eggs containing mRNA, protein, and nutrients necessary for zygotic development (TADROS \& LIPSHITZ, 2009). After fertilization, the genetic material deposited by the female in the oocyte controls the majority of the early events of embryogenesis (DE RENZIS et al., 2007).

MZT occurs in a variety of organisms including echinoderms, nematodes, insects, fish, amphibians, and mammals. The MZT of Drosophila melanogaster is completed in about 2.5 hours. In the mouse MZT occurs within approximately 22 hours after fertilization (SIMPSON \& WIESCHAUS, 1990). In D. melanogaster; maternal transcript destabilization consists of two major events. The first one is exclusively maternal and occurs after oocyte activation even in the absence of zygotic products, while the second one takes place after zygotic activation (TADROS \& LIPSHITZ, 2009). The RNA binding protein Smaug (SMG) is involved in the maternal transcript destabilization of D. melanogaster (TADROS et al., 2003; SEMOTOK et al., 2005; SEMOTOK et al., 2008).

The first zygotic genes activated during $D$. melanogaster embryogenesis display variants of sequences termed "TAGteam" approximately $500 \mathrm{bp}$ upstream of its transcriptional start sites (TEN BOSCH et al., 2006). Studies have identified that the protein Zelda, which is encoded by the zinc-finger gene $z l d$, binds to the TAGteam promoting its transcription (LIANG et al., 2008). In the $D$. melanogaster embryo, two zygotic clusters are activated during mitotic cycles 8 and 14, and their zygotic mRNA targets are mostly transcription factors (DE RENZIS et al., 2007). Some of these genes are responsible for establishing the anteroposterior (AP) and dorsoventral (DV) axes during the embryonic syncytial and cellular blastoderm stages, while others possibly induce zygotic genome activation (SATIJA \& BRADLEY, 2012). The role of zld during MZT has been recently shown to be conserved in different insect species including a role in posterior embryonic patterning (RIBEIRO et al., 2017).

The majority of the studies on the $D$. melanogaster embryo have focused on transcription factors and signaling molecules during early development. In contrast, much less is currently known about the regulation of the metabolic status during these stages, as a limited number of studies have been conducted in order to investigate this particular aspect of the insect embryogenesis (FRAGA et al., 2013) (Figure 1). 


\section{Drosophila Aedes Rhipicephalus}

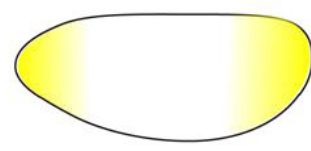

AMNIOSEROSA

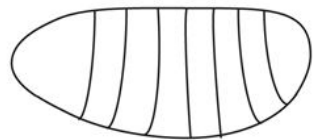

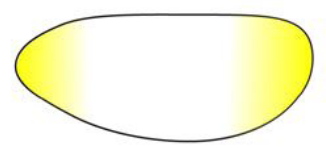

SEROSA and AMNION

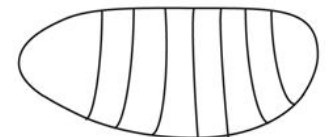

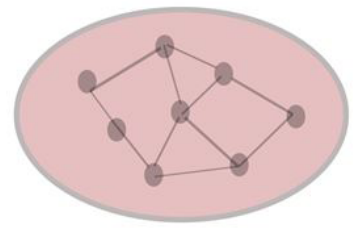

NO EXTRA EMBRYONIC MEMB

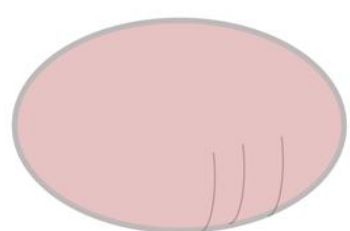

Figure 1. Representation of Rhipicephalus (B.) microplus, Aedes aegypti, Drosophila melagnogaster embryonic development. While chelicerates such as $R$. (B.) microplus do not display extra-embryonic membranes, presumably are cellularized at early stages of development and perform posterior segmentation via a secondary process (SANTOS et al., 2013), mosquitoes and fruit flies are Diptera with long-germ development, where the embryo occupies most of egg length already at early stages of development.

\section{Dynamics of energy metabolism in arthropod vectors}

The blood-sucking arthropod disease vectors are responsible for major epidemics throughout human history such as malaria, yellow fever, plague and Tifo. These arthropods display a great challenge for biological control, since they are responsible for thousands of deaths, causing great harm on public health in the world. Among these arthropod vectors, the mosquito Aedes aegypti is responsible for the largest disease transmission rates in tropical and subtropical countries. This mosquito transmits chikungunya, zika, dengue and yellow fever virus, both of particular importance in Brazil, where it is estimated that 50 million dengue infections occur annually (BRASIL, 2017). Other important vectors of diseases are the ticks, affecting both human and animal population in these countries, transmitting babesiosis, ricketisiosis and anaplasmosis (SILVA \& SILVA, 1999; CORSON et al., 2004; SONENSHINE et al., 2006). Ticks cause considerable losses to the cattle industry worldwide and incur substantial damage to livestock (GRISI et al., 2014). Altogether the economic losses caused by $R$. (B.) microplus to livestock industry and the cost of tick control in Brazil, are estimated at 3 billion U.S. dollars per year (GRISI et al., 2014).

Research groups around the world have studied the disease vectors energy metabolism in order to find possible targets to control these arthropods. Nutrient synthesis and degradation are the basis of life, allowing growth and reproduction, maintaining their structures to correctly respond to their environment. This set of reactions is called metabolism, which must be finely adjusted in order to maintain the energy integrity of the organism. Therefore, the understanding of arthropod dynamic energy metabolism and its nutrients utilization contribute to effective drug and vaccine development to control these vectors. However, despite the current literature provide extensive information on the metabolic events during larval and adult stage of arthropod vectors (CHANDRA, et al., 2008; SERVICE, 1983; RAGHAVENDRA \& SUBBARAO, 2002) other important life cycle stages, such as embryogenesis have been largely neglected.

\section{Embryogenesis in Arthropods}

Embryogenesis has been typically described as an energy consuming process (THOMPSON \& STEWART, 1997; VLECK \& HOYT, 1991). In such context, energy metabolism needs to be finely regulated since the egg constitutes a closed system which relies solely on yolk contents for embryo energy maintenance and organ development (FAGOTTO, 1990; YAMAMOTO \& TAKAHASHI 1993, LOGULLO et al., 1998). Once embryonic development is complete, hatching occurs. Yolk remains inside the midgut of the larval tick (Taheri et al., 2014). During the starvation period, ticks are sustained by reserve substances stored in their midguts (LOGULLO et al., 1998). Larval stages of the Lone Star Tick Amblyomma americanun can survive starvation for approximately 8 months whereas the nymphal and adult stages are able to survive starvation for 6 months and 19 months, respectively (GODDARD \& VARELA-STOKES, 2009) (Figure 1).

Other tick species can survive longer periods without feeding such as the adult stages of Ornithodoros erraticus that under natural conditions can withstand starvation for several years (PALMA et al., 2012). Larvae of the tick Amblyomma spp. can survive starvation for 6 months while nymphs of this tick species can survive up to 12 months of starvation (DIAMANT \& STRICKLAND, 1965). In extreme climatic conditions, larval stages of the tick $R$. (B.) microplus can survive over 6 months without feeding (GONZALES et al., 1974). A dynamic regulation of energy metabolism is required for ticks to survive without feeding for prolonged periods of time. 


\section{Energy metabolism in the arthropod embryo}

Our research group has investigated the mechanisms underlying energy metabolism during the embryonic development of the cattle tick $R$. (B.) microplus. Our results have provided insights into the dynamics of nutrient utilization during tick embryogenesis. Information generated from our studies may help finding candidate antigens for the development of vaccines against ticks (MORAES et al., 2007; LOGULLO et al., 2009; FABRES et al., 2010; ABREU et al., 2013).

The study of molecules that participate in intracellular pathways of the developing tick embryo could reveal the complex networks that regulate metabolism during embryonic development in various organisms. Thus, research characterizing control mechanisms and identifying key enzymes involved in the energy metabolism of $R$. (B.) microplus may help in the identification of potential new vaccine target antigens in order to develop novel immunotherapeutic strategies against the cattle tick and implement efficient tick eradication and control measures (CAMPOS et al., 2006; MORAES et al., 2007).

Our findings indicate that there is mutual regulation among major enzymes of glucose metabolism at the transcriptional and enzymatic levels (SILVA et al., 2015). In our metabolomics research, metabolite levels from metabolic routes in $D$. melanogaster were measured. This approach furthered our understanding of substrates involved in carbohydrate catabolism and anabolic pathways of insects (AN et al., 2014). These findings have expanded our knowledge about the physiology of hematophagous arthropods and energy metabolism of ticks (MORAES et al., 2007; LOGULLO et al. 2009; SILVA et al., 2015). Furthermore, the investigation of key components of these metabolic pathways has provided invaluable information for the development and improvement of vaccines and drugs to control important disease vectors. Although these events are primarily studied in embryonic cells or during embryogenesis (ABREU et al., 2013; AN et al., 2014), some of the aspects of glucose metabolism have also been investigated in adult arthropod tissues and organs before or after a blood meal (VITAL et al., 2010).

There is a relationship between blood ingested and the number of eggs laid in hematophagous arthropods (Table 1). The female adult tick must have a blood meal in order to complete oogenesis and consequently their reproductive success since all the nutrients required for oogenesis are present in the ingested blood (GRIMES, 1980). Table 1 shows the following information about the feeding habits of three different species of hematophagous arthropods Rhipicephalus (B.) microplus, Rhodnius prolixus, and Aedes aegypti: the weight gain of the blood-feeding arthropod after a blood meal; the number of eggs laid by these females after a blood meal; and the volume blood ingested by these females during one blood meal. These classical studies often investigate the hormonal signaling that regulates the synthesis and transport of nutrients from the fatty body to the ovaries, and consequently their deposition in the oocytes in response of the blood meal. Therefore, these studies did not focus on the maternal-zygotic transition or on the energy metabolism of the embryo itself.

In arthropods, classical studies on embryonic metabolism have demonstrated that glycogen reserves are important to sustain the development of the embryo (FAGOTTO, 1990; MORAES et al., 2007, CAMPOS et al., 2006, LOGULLO et al., 2009; VITAL et al., 2010). During Drosophila melanogaster oogenesis, glycogen is predominantely accumulated in mature ovarian follicles and is a major storage form of carbohydrate in eggs (GUTZEIT et al., 1993). In the early stages of Drosophila embryogenesis, protein metabolism and glycogen metabolism are negatively correlated since total protein levels decline as glycogen levels increase (SHIOMI \& KITAZUME, 1956; MEDINA AND VALLEJO, 1989; GUTZEIT et al., 1993). Other studies have shown that glycogen levels vary during Drosophila embryogenesis, and that abundant glycogen stores are present during the late stages of the fly embryogenesis (YAMAZAKI \& NUSSE, 2002; YAMAZAKI \& YANAGAWA, 2003).

Glycogen metabolism during the embryonic development of the tick $R$. (B.) microplus is similar to that of the fly D. melanogaster. During early development of the tick embryo, glycogen degradation occurs while during the late stages of embryogenesis glycogen reserves are resynthesized and protein degradation ensues. Additionally, the proteomic profiles of sequential stages of $R$. (B.) microplus ovaries have been studied and showed the temporal dynamics of the proteins during ovary development. It was observed a significant variation in the levels of proteins involved in carbohydrate metabolism, especially enzymes involved in glycogen metabolism (XAVIER et al., 2018).

During the final stage of tick embryogenesis, gluconeogenesis is intensified to provide the embryo with an adequate glucose supply. Amino acids play an important role as substrates for gluconeogenesis and subsequent glycogen resynthesis during the final stages of embryogenesis in these arthropods (MORAES et al., 2007). During the embryogenesis of Rhipicephalus (B.) microplus, lipids, carbohydrates and proteins are used as major energy sources (Figure 2), Our studies show that gluconeogenesis makes a significant contribution to maintain the energy balance in the late stages of

Table 1. Comparison between three different species of hematophagous arthropods - Rhipicephalus (B.) microplus, Rhodnius prolixus, and Aedes aegypti - with regard to their feeding habits: the volume blood ingested by a female during one blood meal; the weight gain of the bloodfeeding arthropod after a blood meal, and the number of eggs laid by these females after a blood meal.

\begin{tabular}{cccc}
\hline & Rhipicephalus (B.) microplus & Rhodnius prolixus & Aedes aegypti \\
\hline Blood volume ingested & $300-500 \mu \mathrm{l}$ & $297 \mu \mathrm{l}^{* *}$ & $2,5 \mu \mathrm{l}$ \\
Weight gain after a blood meal & $150-200 \mathrm{mg}$ & $236,8 \mathrm{mg}$ & $3 \mathrm{mg}$ \\
Number of eggs laid* & 3000 & 574 & 75 \\
\hline
\end{tabular}

*The number of eggs laid is mean values per female; **The volume of blood is the average flow rate of 0,33 $\mu$ l per second.Sources: (BUXTON, 1930; WOKE et al., 1956; DAVEY et al., 1986; MADEIRA et al., 2002; ARÉVALO et al., 2007; RUEGG \& DAVEY, 2012; REY \& O'CONNELL, 2014). 


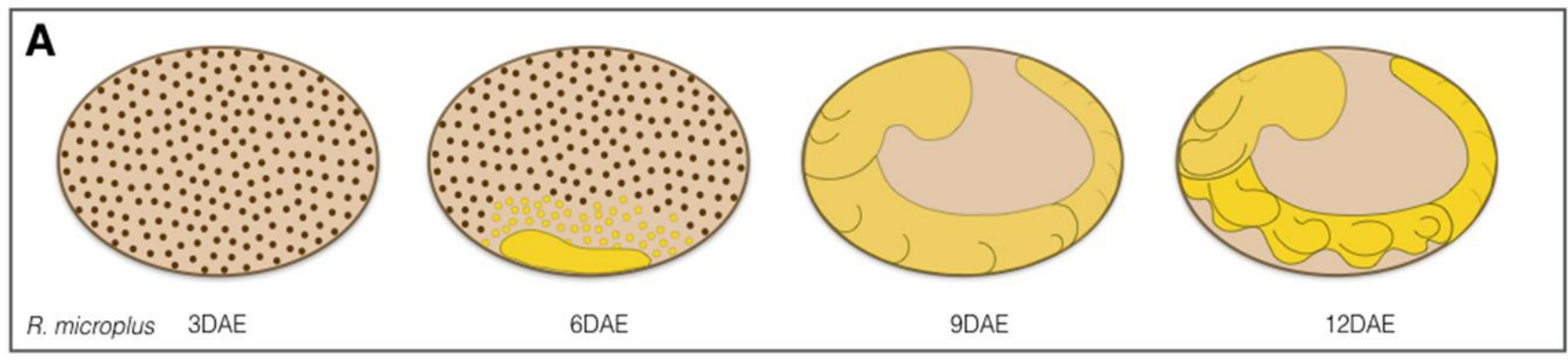

B

Carbohydrate

Lipids

Protein

Figure 2. Dynamic of energy source during embryogenesis of $R$. (B.) microplus. In early development. The description of energy source utilization (B) during $R$. (B.) microplus embryogenesis (A) shows that the first energy source mobilized is lipids, in middle and late of development carbohydrate and protein are recruited and glycogen is resynthesized. DAE (days after eggs laying).

R. (B.) microplus embryo development (MORAES et al., 2007; LOGULLO et al., 2009; FABRES et al., 2010).

During gluconeogenesis, glucose is generated from non-glycosidic compounds. This metabolic pathway is regulated by phosphoenolpyruvate carboxykinase (PEPCK) which is an enzyme that catalyzes the initial steps of gluconeogenesis (BALLARD \& OLIVER 1963; BALLARD et al., 1967). When glucose levels are low, as during the early stages of tick embryonic development, the rate of gluconeogenesis increases. In this scenario, PEPCK activity in gluconeogenesis is increased. Transcription of the gene for this enzyme is controlled by several hormones and is tissue-specific (CHAKRAVARTY et al., 2005).

In one study about glucose metabolism during the embryogenesis of R. (B.) microplus Moraes et al. (2007) found that PEPCK activity increases as glycogen is re-synthesized. These findings suggest that glucose may form from other substrates through this pathway ensuring glycogen re-synthesis. PEPCK dynamics, activity and regulation during Aedes aegypti embryogenesis are different from those of $R$. (B.) microplus embryonic development. During the early stages of embryogenesis of this mosquito, PEPCK activity is low. PEPCK activity increases as embryogenesis progresses until it reaches high levels which are kept high until hatching (VITAL et al., 2010). These results suggest that, in addition to PEPCK activity, gluconeogenesis may also have an important role in maintaining the embryo viability.

\section{Embryo proteins as targets for tick control}

The identification and characterization of molecules involved in embryonic development support to a better understanding of the tick parasite physiology and can help to select potential targets to the development of new tick control methods. With this objective, various enzymes have been tested as targets to immunological or chemical controls. Immunization of bovines with an egg-yolk aspartic endopeptidase (Boophilus Yolk pro-cathepsin (BYC) (SILVA VAZ et al., 1998; LEAL et al., 2006) or a $R$. (B.) microplus cysteine endopeptidase (VTDCE) (SEIXAS et al., 2008), enzymes involved in the digestion of vitellin, interfered with the reproductive process of the tick, interfering with embryo development. Effects in embryogenesis also were observed by immunization of rabbits and cattle with a ferritin, an iron-storage protein (HAJDUSEK et al., 2010). Also, hamster immunized with Ixodes persulcatus CDK10 (a cyclin-dependent kinase, involved in cell cycle control showed a partial protective immune response against tick infestations (GOMES et al., 2015).

Other tick proteins important in embryogenesis have been studied as target for control. A $R$. (B.) microplus triosephosphate isomerase (TIM), an fundamental enzyme in the energy metabolism during embryogenesis was be inhibited by antibodies (SARAMAGO et al., 2012) and by sulfhydryl reagents that interfere in essential cysteine residues of the BmTIM (MORAES et al., 2011). Also, a catalase inhibitor (3-amino-1,2,4-triazole) induced deleterious effects to $R$. (B.) microplus, interfering in oogenesis and oviposition (CITELLI et al., 2007). Also, the interference in the physiology function of $\mathrm{Hq} 05$ and $\mathrm{Bm} 05 \mathrm{br}$, two homologous proteins involve, respectively, in Haemaphysalis qinghaiensis (GAO et al., 2009) and $R$. (B.) microplus (ALZUGARAY et al., 2017) reproduction induced alteration in tick embryo development. Taken together, these results suggest that various tick proteins with important role in embryogenesis can be promising targets to development of new methods for the parasite control. 


\section{Conclusion}

The metabolic requirements of the developing tick embryo and the mechanisms regulating embryogenesis in arthropods have been extensively studied by many researchers over the years and are now well-established and well-characterized. However, some aspects of the tick embryo physiology remains unclear. Glucose metabolism plays an essential role during embryonic development and viability of various species. There is an increasing body of knowledge gained from research regarding glucose metabolism in the tick embryo. Information generated in these studies will give us a comprehensive view of the dynamics of this metabolic pathway during tick embryogenesis.

\section{References}

Abreu LA, Calixto C, Waltero CF, Della Noce BP, Githaka NW, Seixas A, et al. The conserved role of the AKT/GSK3 axis in cell survival and glycogen metabolism in Rhipicephalus (Boophilus) microplus embryo tick cell line BME26. Biochim Biophys Acta 2013; 1830(3): 2574-2582. http:// dx.doi.org/10.1016/j.bbagen.2012.12.016. PMid:23274741.

Alzugaray MF, Parizi LF, Seixas A, Benavides U, Silva Vaz I Jr. Molecular and functional characterization of Bm05br antigen from Rhipicephalus microplus. Ticks Tick Borne Dis 2017; 8(2): 320-329. http://dx.doi. org/10.1016/j.ttbdis.2016.12.008. PMid:28043800.

An PNT, Yamaguchi M, Bamba T, Fukusaki E. Metabolome analysis of Drosophila melanogaster during embryogenesis. PLoS One 2014; 9(8): e99519. http://dx.doi.org/10.1371/journal.pone.0099519. PMid:25121768.

Arévalo A, Carranza JC, Guhl F, Clavijo JA, Vallejo GA. Comparación del ciclo de vida de Rhodnius colombiensis Moreno, Jurberg \& Galvão, 1999 y Rhodnius prolixus Stal, 1872 (Hemiptera, Reduviidae, Triatominae) en condiciones de laboratorio. Biomedica 2007;27(S1 Suppl 1): 119-129. http://dx.doi.org/10.7705/biomedica.v27i1.255. PMid:18154252.

Ballard FJ, Hanson R, Leveille G. Phosphoenolpyruvate carboxykinase and the synthesis of glyceride-glycerol from pyruvate in adipose tissue. J Biol Chem 1967; 242(11): 2746-2750. PMid:6027245.

Ballard FJ, Oliver I. Glycogen metabolism in embryonic chick and neonatal rat liver. Biochim Biophys Acta 1963; 71: 578-588. http://dx.doi. org/10.1016/0006-3002(63)91130-2. PMid:13966157.

Brasil. Ministério da Saúde. Secretaria de Vigilância em Saúde. Virus zika Brasil resposta SUS. 1. ed. [online] Brasília: Ministério da Saúde; 2017 [cited 2018 Feb 2]. Available from: http://bvsms.saude.gov.br/bvs/ publicacoes/virus_zika_brasil_resposta_sus.pdf

Briegel H, Gut T, Lea AO. Sequential deposition of yolk components during oogenesis in an insect, Aedes aegypti (Diptera: Culicidae). J Insect Physiol 2003; 49(3): 249-260. http://dx.doi.org/10.1016/S00221910(02)00272-X. PMid:12770000.

Brown MR, Clark KD, Gulia M, Zhao Z, Garczynski SF, Crim JH, et al. An insulin-like peptide regulates egg maturation and metabolism in the mosquito Aedes aegypti. Proc Natl Acad Sci USA 2008; 105(15): 57165721. http://dx.doi.org/10.1073/pnas.0800478105. PMid:18391205.

Buxton PA. The biology of a blood sucking bug Rhodnius prolixus. Trans Entomol Soc Lond 1930; 78(2): 227-256. http://dx.doi. org/10.1111/j.1365-2311.1930.tb00385.x.
Campos E, Moraes J, Façanha AR, Moreira E, Valle D, Abreu L, et al. Kinetics of energy source utilization in Boophilus microplus (Canestrini, 1887) (Acari: Ixodidae) embryonic development. Vet Parasitol 2006; 138(3-4): 349-357. http://dx.doi.org/10.1016/j.vetpar.2006.02.004. PMid:16569482.

Chakravarty K, Cassuto H, Reshef L, Hanson RW. Factors that control the tissue-specific transcription of the gene for phosphoenolpyruvate carboxykinase-C. Crit Rev Biochem Mol Biol 2005; 40(3): 129-154. http://dx.doi.org/10.1080/10409230590935479. PMid:15917397.

Chandra G, Bhattacharjee I, Chatterjee SN, Ghosh A. Mosquito control by larvivorous fish. Indian J Med Res 2008; 127(1): 13-27. PMid:18316849.

Chippendale GM. Carbohydrates in reproduction and embryonic development. In: Rockstein M. Biochemistry of Insects. New York: Academic Press; 1978.

Citelli M, Lara FA, Silva Vaz I Jr, Oliveira PL. Oxidative stress impairs heme detoxification in the midgut of the cattle tick, Rhipicephalus (Boophilus) microplus. Mol Biochem Parasitol 2007; 151(1): 81-88. http://dx.doi. org/10.1016/j.molbiopara.2006.10.008. PMid:17123644.

Corson MS, Teel PD, Grant WE. Microclimate influence in a physiological model of cattle-fever tick (Boophilus spp.) population dynamics. Ecol Modell 2004; 180(4): 487-514. http://dx.doi.org/10.1016/j.ecolmodel.2004.04.034

Davey KG, Maimets K, Ruegg RP. The relationship between crop size and egg production in Rhodnius prolixus. Can J Zool 1986; 64(12): 26542657. http://dx.doi.org/10.1139/z86-385.

Davis GK, Patel NH. Short, long, and beyond: molecular and embryological approaches to insect segmentation. Annu Rev Entomol 2002; 47(1): 669-699. http://dx.doi.org/10.1146/annurev.ento.47.091201.145251. PMid:11729088.

De Renzis S, Elemento O, Tavazoie S, Wieschaus EF. Unmasking activation of the zygotic genome using chromosomal deletions in the Drosophila embryo. PLoS Biol2007; 5(5): e117. http://dx.doi.org/10.1371/journal. pbio.0050117. PMid:17456005.

Diamant G, Strickland RK. Manual on livestock ticks for animal disease eradication personnel. Washington: U.S. Department of Agriculture, Agricultural Research Service; 1965.

Fabres A, Andrade CP, Guizzo M, Sorgine MH, Paiva-Silva GO, Masuda A, et al. Effect of GSK-3 activity, enzymatic inhibition and gene silencing by RNAi on tick oviposition and egg hatching. Parasitology 2010; 137(10): 1537-1546. http://dx.doi.org/10.1017/S0031182010000284. PMid:20500916.

Fagotto F. Yolk degradation in tick eggs: I. Occurrence of a cathepsin L-like acid proteinase in yolk spheres. Arch Insect Biochem Physiol 1990; 14(4): 217-235. http://dx.doi.org/10.1002/arch.940140403. PMid:2134178.

Fraga A, Ribeiro L, Lobato M, Santos V, Silva JR, Gomes H, et al. Glycogen and glucose metabolism are essential for early embryonic development of the red flour beetle Tribolium castaneum. PLoS One 2013; 8(6): e65125. http://dx.doi.org/10.1371/journal.pone.0065125. PMid:23750237.

Gao J, Luo J, Fan R, Schulte-Spechtel UC, Fingerle V, Guan G, et al. Characterization of a concealed antigen $\mathrm{Hq} 05$ from the hard tick Haemaphysalis qinghaiensis and its effect as a vaccine against tick infestation in sheep. Vaccine 2009; 27(3): 483-490. http://dx.doi.org/10.1016/j. vaccine.2008.10.067. PMid:19010370.

Goddard J, Varela-Stokes AS. Role of the lone star tick, Amblyomma americanum (L.), in human and animal diseases. Vet Parasitol 2009; 160(1-2): 1-12. http://dx.doi.org/10.1016/j.vetpar.2008.10.089. PMid:19054615. 
Goldstrohm DA, Pennington JE, Wells MA. The role of hemolymph proline as a nitrogen sink during blood meal digestion by the mosquito Aedes aegypti. J Insect Physiol 2003; 49(2): 115-121. http://dx.doi. org/10.1016/S0022-1910(02)00267-6. PMid:12770004.

Gomes H, Moraes J, Githaka N, Martins R, Isezaki M, Vaz IS Jr, et al. Vaccination with cyclin-dependent kinase tick antigen confers protection against Ixodes infestation. Vet Parasitol 2015; 211(3-4): 266-273. http:// dx.doi.org/10.1016/j.vetpar.2015.05.022. PMid:26073111.

Gonzales JC, Silva NR, Wagner EM. O ciclo parasitário do Boophilus microplus (Can., 1887) em bovinos estabulados. Arq Fac Vet UFRGS 1974; 2(1): 25-34.

Grimes AJ. Human red cell metabolism. Oxford: Blackwell Scientific Publications; 1980.

Grisi L, Leite RC, Martins JRS, Barros ATM, Andreotti R, Cançado PHD, et al. Reassessment of the potential economic impact of cattle parasites in Brazil. Rev Bras Parasitol Vet 2014; 23(2): 150-156. http:// dx.doi.org/10.1590/S1984-29612014042. PMid:25054492.

Gutzeit HO, Zissler D, Fleig R. Oogenesis in the honeybee Apis mellifera: cytological observations on the formation and differentiation of previtellogenic ovarian follicles. Rouxs Arch Dev Biol 1993; 202(3): 181-191. http://dx.doi.org/10.1007/BF00365309. PMid:28305996.

Hajdusek O, Almazán C, Loosova G, Villar M, Canales M, Grubhoffer $\mathrm{L}$, et al. Characterization of ferritin 2 for the control of tick infestations. Vaccine 2010; 28(17): 2993-2998. http://dx.doi.org/10.1016/j. vaccine.2010.02.008. PMid:20171306.

Leal AT, Seixas A, Pohl PC, Ferreira CA, Logullo C, Oliveira PL, et al. Vaccination of bovines with recombinant Boophilus Yolk pro-Cathepsin. Vet Immunol Immunopathol 2006; 114(3-4): 341-345. http://dx.doi. org/10.1016/j.vetimm.2006.08.011. PMid:16997384.

Liang HL, Nien CY, Liu HY, Metzstein MM, Kirov N, Rushlow C. The zinc-finger protein Zelda is a key activator of the early zygotic genome in Drosophila. Nature 2008; 456(7220): 400-403. http://dx.doi.org/10.1038/ nature07388. PMid:18931655.

Logullo C, Vaz IS, Sorgine MHF, Paiva-Silva GO, Faria FS, Zingali $\mathrm{RB}$, et al. Isolation of an aspartic proteinase precursor from the egg of a hard tick, Boophilus microplus. Parasitology 1998; 116(Pt 6): 525-532. http://dx.doi.org/10.1017/S0031182098002698. PMid:9651935.

Logullo C, Witola WH, Andrade C, Abreu L, Gomes J, Silva Vaz I $\mathrm{Jr}$, et al. Expression and activity of glycogen synthase kinase during vitellogenesis and embryogenesis of Rhipicephalus (Boophilus) microplus. Vet Parasitol 2009; 161(3-4): 261-269. http://dx.doi.org/10.1016/j. vetpar.2009.01.029. PMid:19285806.

Lynch J, Desplan C. Evolution of Development: Beyond Bicoid. Curr Biol 2003; 13(14): R557-R559. http://dx.doi.org/10.1016/S09609822(03)00472-X. PMid:12867048.

Madeira NG, Macharelli CA, Carvalho LR. Variation of the oviposition preferences of Aedes aegypti in function of substratum and humidity. Mem Inst Oswaldo Cruz 2002; 97(3): 415-420. http://dx.doi.org/10.1590/ S0074-02762002000300025. PMid:12048575.

Medina M, Vallejo CG. The contents of proteins, carbohydrates, lipids and DNA during the embryogenesis of Drosophila. Int J Dev Biol 1989; 33(3): 403-405. PMid:2518452.

Moraes J, Arreola R, Cabrera N, Saramago L, Freitas D, Masuda A, et al. Structural and biochemical characterization of a recombinant triosephosphate isomerase from Rhipicephalus (Boophilus) microplus. Insect
Biochem Mol Biol 2011; 41(6): 400-409. http://dx.doi.org/10.1016/j. ibmb.2011.02.009. PMid:21396445.

Moraes J, Galina A, Alvarenga PH, Rezende GL, Masuda A, Silva Vaz I Jr, et al. Glucose metabolism during embryogenesis of the hard tick Boophilus microplus. Comp Biochem Physiol A Mol Integr Physiol 2007; 146(4): 528-533. http://dx.doi.org/10.1016/j.cbpa.2006.05.009. PMid:16904922.

Nüsslein-Volhard C, Frohnhofer HG, Lehmann R. Determination of anteroposterior polarity in Drosophila. Science 1987; 238(4834): 16751681. http://dx.doi.org/10.1126/science.3686007. PMid:3686007.

Nüsslein-Volhard C, Wieschaus E. Mutations affecting segment number and polarity in Drosophila. Nature 1980; 287(5785): 795-801. http:// dx.doi.org/10.1038/287795a0. PMid:6776413.

Ober U, Ayroles JF, Stone EA, Richards S, Zhu D, Gibbs RA, et al. Using whole-genome sequence data to predict quantitative trait phenotypes in Drosophila melanogaster. PLoS Genet 2012; 8(5): e1002685. http://dx.doi. org/10.1371/journal.pgen.1002685. PMid:22570636.

Palma M, Lopes de Carvalho I, Figueiredo M, Amaro F, Boinas F, Cutler SJ, et al. Borrelia hispanica in Ornithodoros erraticus, Portugal. Clin Microbiol Infect 2012; 18(7): 696-701. http://dx.doi.org/10.1111/j.14690691.2011.03623.x. PMid:21883668.

Prpic NM, Schoppmeier M, Damen WGM. Gene Silencing via Embryonic RNAi in Spider Embryos. CSH Protoc 2008; 2008(10): 01-04.

Raghavendra K, Subbarao SK. Chemical insecticides in malaria vector control in India. Icmr Bull 2002; 32: 93-99.

Rey JR, O'Connell SM. Oviposition by Aedes aegypti and Aedes albopictus Influence of congeners and of oviposition site characteristics. J Vector Ecol 2014; 39(1): 190-196. http://dx.doi.org/10.1111/j.19487134.2014.12086.x. PMid:24820572.

Ribeiro L, Tobias-Santos V, Santos D, Antunes F, Feltran G, de Souza Menezes J, et al. Evolution and multiple roles of the Pancrustacea specific transcription factor Zelda in insects. PLoS Genet 2017; 13(7): e1006868. http://dx.doi.org/10.1371/journal.pgen.1006868. PMid:28671979.

Roy S, Ernst J, Kharchenko PV, Kheradpour P, Negre N, Eaton ML, et al. Identification of functional elements and regulatory circuits by Drosophila modENCODE. Science 2010; 330(6012): 1787-1797. http://dx.doi. org/10.1126/science.1198374. PMid:21177974.

Ruegg RP, Davey KG. The effect of C18 juvenile hormone and Altosid on the efficiency of egg production in Rhodnius prolixus. Int J Invertebr Reproduct 2012; 1(1): 3-8. http://dx.doi.org/10.1080/01651269.1979.1 0553294 .

Santos VT, Ribeiro L, Fraga A, Barros CM, Campos E, Moraes J, et al. The embryogenesis of the tick Rhipicephalus (Boophilus) microplus: the establishment of a new chelicerate model system. Genesis 2013; 51(12): 803-818. http://dx.doi.org/10.1002/dvg.22717. PMid:24166799.

Sappington TW, Raikhel AS. Molecular characteristics of insect vitellogenins and vitellogenin receptors. Insect Biochem Mol Biol 1998; 28(5-6): 277-300. http://dx.doi.org/10.1016/S0965-1748(97)00110-0. PMid:9692232.

Saramago L, Franceschi M, Logullo C, Masuda A, Vaz IS Jr, Farias SE, et al. Inhibition of enzyme activity of Rhipicephalus (Boophilus) microplus triosephosphate isomerase and BME26 cell growth by monoclonal antibodies. Int J Mol Sci 2012; 13(10): 13118-13133. http://dx.doi. org/10.3390/ijms131013118. PMid:23202941.

Satija R, Bradley RK. The TAGteam motif facilitates binding of 21 sequence-specific transcription factors in the Drosophila embryo. Genome 
Res 2012; 22(4): 656-665. http://dx.doi.org/10.1101/gr.130682.111. PMid:22247430.

Seixas A, Leal AT, Nascimento-Silva MC, Masuda A, Termignoni C, da Silva Vaz I Jr. Vaccine potential of a tick vitellin-degrading enzyme (VTDCE). Vet Immunol Immunopathol 2008; 124(3-4): 332-340. http:// dx.doi.org/10.1016/j.vetimm.2008.04.001. PMid:18490061.

Semotok JL, Cooperstock RL, Pinder BD, Vari HK, Lipshitz HD, Smibert CA. Smaug recruits the CCR4/POP2/NOT deadenylase complex to trigger maternal transcript localization in the early Drosophila embryo. Curr Biol 2005; 15(4): 284-294. http://dx.doi.org/10.1016/j. cub.2005.01.048. PMid:15723788.

Semotok JL, Westwood JT, Goldman AL, Cooperstock RL, Lipshitz HD. Measuring mRNA stability during early Drosophila embryogenesis. Methods Enzymol 2008; 448: 299-334. http://dx.doi.org/10.1016/S00766879(08)02616-5. PMid:19111183.

Service MW. Biological control of mosquitoes - has it a future? Mosq News 1983; 43(2): 113-120.

Shiomi T, Kitazume Y. Changes in glycogen content during early embryonic development in Drosophila melanogaster. Drosoph Inf Serv 1956; 30: 151-152.

Silva HHG, Silva IG. Influência do período de quiescência dos ovos sobre o ciclo de vida de Aedes aegypti (Linnaeus, 1762) (Diptera, Culicidae) em condiçōes de laboratório. Rev Soc Bras Med Trop 1999; 32(4): 349-355. http://dx.doi.org/10.1590/S0037-86821999000400003. PMid:10495662.

Silva RM, Noce BD, Waltero CF, Costa EP, Abreu LA, Githaka NW, et al. Non-Classical Gluconeogenesis-Dependent glucose metabolism in Rhipicephalus microplus embryonic cell line BME26. Int J Mol Sci 2015; 16(1): 1821-1839. http://dx.doi.org/10.3390/ijms16011821. PMid:25594873.

Silva Vaz I Jr, Logullo C, Sorgine M, Velloso FF, Rosa de Lima MF, Gonzales JC, et al. Immunization of bovines with an aspartic proteinase precursor isolated from Boophilus microplus eggs. Vet Immunol Immunopathol 1998; 66(3-4): 331-341. http://dx.doi.org/10.1016/S0165-2427(98)00194-9. PMid:9880109.

Simpson L, Wieschaus EF. Zygotic activity of the nullo locus is required to stabilize the actin-myosin network during cellularization in Drosophila. Development 1990; 110(3): 851-863. PMid:2088725.

Sonenshine DE, Kocan KM, de la Fuente J. Tick control: further thoughts on a research agenda. Trends Parasitol 2006; 22(12): 550-551. http:// dx.doi.org/10.1016/j.pt.2006.09.003. PMid:17005451.

Tadros W, Houston SA, Bashirullah A, Cooperstock RL, Semotok JL, Reed BH, et al. Regulation of Maternal Transcript Destabilization During Egg Activation in Drosophila. Genetics 2003; 164(3): 989-1001. PMid:12871909.

Tadros W, Lipshitz HD. The maternal-to-zygotic transition: a play in two acts. Development 2009; 136(18): 3033-3042. http://dx.doi.org/10.1242/ dev.033183. PMid:19700615.
Taheri M, Nabian S, Ranjbar M, Mazaheri Nezhad R, Gerami Sadeghian A, Sazmand A. Study of vitellogenin in Boophilus annulatus tick larvae and its immunological aspects. Trop Biomed 2014; 31(3): 398-405. PMid:25382465.

ten Bosch JR, Benavides JA, Cline TW. The TAGteam DNA motif controls the timing of Drosophila pre-blastoderm transcription. Development 2006; 133(10): 1967-1977. http://dx.doi.org/10.1242/dev.02373. PMid:16624855.

Thompson M, Stewart JR. Stewart jR. Embryonic metabolism and growth in lizards of the genus Eumeces. Comp Biochem Physiol 1997; 118(3): 647-654. http://dx.doi.org/10.1016/S0300-9629(97)00081-9.

Vital W, Rezende GL, Abreu L, Moraes J, Lemos FJ, Vaz IS Jr, et al. Germ band retraction as a landmark in glucose metabolism during Aedes aegypti embryogenesis. BMC Dev Biol 2010; 10(1): 25. http://dx.doi. org/10.1186/1471-213X-10-25. PMid:20184739.

Vleck C, Hoyt D. Metabolism and energetic of reptilian and avian embryos. In: Deeming DC, Ferguson MWJ. Egg incubation: its effects on embryonic development in birds and reptiles. Cambridge Univ. Press: Cambridge, 1991. p. 285-306. http://dx.doi.org/10.1017/CBO9780511585739.019.

Woke PA, Ally MS, Rosenberger CRJ Jr. The numbers of eggs developed related to the quantities of human blood ingested in Aedes aegypti (L.) (Diptera: Culicidae). Ann Entomol Soc Am 1956; 49(5): 435-441. http:// dx.doi.org/10.1093/aesa/49.5.435.

Xavier MA, Tirloni L, Pinto AFM, Diedrich JK, Yates JR 3rd, Mulenga A, et al. A proteomic insight into vitellogenesis during tick ovary maturation. Sci Rep 2018; 8(1): 4698. http://dx.doi.org/10.1038/s41598018-23090-2. PMid:29549327.

Yamamoto Y, Takahashi SY. Cysteine proteinase from Bombyx eggs: role in programmed degradation of yolk proteins during embryogenesis. Comp Biochem Physiol B 1993; 106(1): 35-45. http://dx.doi.org/10.1016/03050491(93)90004-O. PMid:8403852.

Yamazaki H, Nusse R. Identification of DCAP, a drosophila homolog of a glucose transport regulatory complex. Mech Dev 2002; 119(1): 115-119. http://dx.doi.org/10.1016/S0925-4773(02)00307-6. PMid:12385759.

Yamazaki H, Yanagawa S. Axin and the Axin/Arrow-binding protein DCAP mediate glucose-glycogen metabolism. Biochem Biophys Res Commun 2003; 304(2): 229-235. http://dx.doi.org/10.1016/S0006291X(03)00582-5. PMid:12711303.

Zhou G, Flowers M, Friedrich K, Horton J, Pennington J, Wells MA. Metabolic fate of [14C]-labeled meal protein amino acids in Aedes aegypti mosquitoes. J Insect Physiol 2004a; 50(4): 337-349. http://dx.doi. org/10.1016/j.jinsphys.2004.02.003. PMid:15081827.

Zhou G, Pennington JE, Wells MA. Utilization of pre-existing energy stores of female Aedes aegypti mosquitoes during the first gonotrophic cycle. Insect Biochem Mol Biol 2004b; 34(9): 919-925. http://dx.doi. org/10.1016/j.ibmb.2004.05.009. PMid:15350611. 